\title{
De besturing van interne transacties
}

\section{Een verrijking van de theorie van Eccles}

\section{Dr. J. van der Meer-Kooistra}

De coördinatie van interne transacties is een complex afstemmingsvraagstuk. Eccles (1985) heeft een theorie ontwikkeld om dit vraagstuk in de praktijk op te lossen. Het werk van Eccles kan worden beschouwd als een internationaal standaardwerk. Wii hebben onderzoek gedaan naar het functioneren van systemen van interne verrekenprijzen. Op grond hiervan kunnen we vaststellen dat het model van Eccles onvoldoende houvast biedt voor het verklaren van het verrekenprijsbeleid. In dit artikel komen we met aanvullingen op de gedachten van Eccles. We ontwikkelen een verklarend model dat inzicht geeft in de factoren die bij de coördinatie van interne transacties een belangrijke rol spelen.

Dit artikel behandelt vooral de theoretische concepten die een verklaring bieden voor de aard van de coördinatie van interne transacties. In een volgend artikel stellen we de empirische data centraal door de bevindingen van het praktijkonderzoek bij Shell Nederland Raffinaderij BV te beschrijven.

\section{$1 \quad$ Inleiding}

Over interne verrekenprijssystemen is in de loop der jaren veel geschreven. De meest recente, uitvoerige behandeling van het vraagstuk van de besturing van interne transacties is van Eccles (1985). Op grond van literatuuren praktijkonderzoek ontwikkelt hij een 'theory for practice' en een model, aan de hand waarvan ondernemingen een verrekenprijsbeleid kunnen opstellen of het bestaande beleid kunnen evalueren. Een belangrijke factor in deze theorie is de strategie van een onderneming, waarbij het gaat om verticale integratie en diversificatie. Eccles laat de vraag: waarom ondernemingen een bepaalde strategie nastreven, onbeantwoord. In het bijzonder betreft het een verklaring voor de strategie van verticale integratie, omdat, aldus Eccles, een strategie van diversificatie afdoende is verklaard

De afgelopen jaren hebben wij diepgaand onderzoek verricht naar het functioneren van interne verrekenprijssystemen, in welk kader wij bij enkele Nederlandse multinationals hebben onderzocht hoe zij hun interne transacties besturen. ${ }^{\top}$ Centraal in dit onderzoek stond de vraag welke factoren de besturingswijze van interne transacties bepalen. Het theoretische model dat in het onderzoek is gehanteerd, is mede gebaseerd op de concepten en ideeën van de transactiekostentheorie. Deze theorie is gericht op het verklaren van de grenzen van een onderneming en beschouwt daarbij de transactie als eenheid van analyse. Een belangrijk aandachtspunt is het verschijnsel verticale integratie, waarvoor de theorie een verklaring geeft die is gebaseerd op de kenmerken van een transactie. Door onder meer gebruik te maken van de gedachten van de transactiekostentheorie hebben wij de ideeën van Eccles verder kunnen uitwer-

Dr. J. van der Meer-Kooistra, registeraccountant, is verbonden aan de Faculteit Bedrijfskunde van de Rijksuniversiteit Groningen en belast met onderwijs en onderzoek op de terreinen management en financial accounting. 
ken. Op grond van de nieuwe inzichten hebben we een verklarend model opgesteld. In dit artikel willen we de belangrijkste uitkomsten van het onderzoek weergeven. Daarbij concentreren we ons op de aanvullingen die we geven op de gedachten van Eccles. Daarom beginnen we het artikel met een overzicht van de ideeën van Eccles (paragraaf 2). Hierna beschrijven we de factoren die, volgens ons onderzoek, de besturingswijze van interne transacties beïnvloeden, en gaan na welke verschillen er zijn tussen deze factoren en het model van Eccles (paragraaf 3 ). Vervolgens onderwerpen we de verschillen aan een nader onderzoek (paragraaf 4 en paragraaf 5). We sluiten het artikel af met een weergave van het verklarende model dat het resultaat is van ons onderzoek, en met enkele conclusies.

\section{Gedachten van Eccles}

Op grond van onderzoek in verschillende ondernemingen concludeert Eccles dat er twee determinanten zijn die het verrekenprijsbeleid bepalen:

1 strategie;

2 administratieve proces

\section{Strategie}

Volgens Eccles beïnvloedt de aard van de strategie de bevoegdheid van de bedrijfsonderdelen aangaande de keuze van de tegenpartij voor de transactie van goederen of diensten en tevens de waardebepaling van de interne transacties. De aard van de strategie wordt bepaald door (a) mate van verticale integratie, en (b), mate van diversificatie. Voor de omschrijving van het begrip verticale integratie hanteert Eccles de definitie van Porter (1980), die luidt: 'the combination of technologically distinct production, distribution, selling, and/ or other economic processes within the confines of a single firm' (p. 300). Eccles stelt dat, indien ondernemingen een strategie van verticale integratie nastreven, interne transacties tussen winstcentra verplicht zijn. Indien de strategie niet is gericht op verticale integratie, wordt de keuze van de leverancier c.q. afnemer aan de winstcentra overgelaten.

Met betrekking tot het begrip verticale integratie maakt Eccles onderscheid tussen achterwaartse verticale integratie en overige strategieën van verticale integratie. Dit onderscheid is volgens Eccles van belang voor de waardebepaling van de interne transacties, ofwel voor de keuze van de verrekenprijs. Indien er sprake is van achterwaartse verticale integratie, wordt de verrekenprijs gebaseerd op kosten. De reden hiervoor is, dat bij achterwaartse verticale integratie het beleid van de onderneming gericht is op het tegen zo laag mogelijke kosten kunnen beschikken over halffabrikaten. Door intern te produceren in plaats van extern in te kopen is de onderneming geen winstopslag verschuldigd, en kunnen bepaalde kosten die verbonden zijn aan een externe transactie, worden vermeden (bijvoorbeeld transportkosten). Eccles spreekt van achterwaartse verticale integratie als 'the resources in the selling profit center devoted to internal sales were considered as much a part of the business of the buying profit center as its own manufacturing facilities' ( $p$. 79). Als het intern verkopende bedrijfsonderdeel daarentegen als een apart bedrijf wordt beschouwd, dat zowel aan interne als aan externe afnemers levert, dan wordt, aldus Eccles, de verrekenprijs gebaseerd op de marktprijs. In de redenering van Eccles gaat het dan om overige strategieën van verticale integratie.

Eccles concludeert dat in geval van diversificatie de winstcentra zelf mogen beslissen of zij met een interne dan wel met een externe partij in zee gaan. Ook de beslissing over de verrekenprijs en de overige transactievoorwaarden wordt aan de winstcentra overgelaten. Bij diversificatie gaat het om the number of different businesses in which the company competes and to how different these businesses are from each other' (p. 272). Hoe groter het aantal produkten en markten waarin een onderneming opereert, hoe groter de verscheidenheid aan 'businesses' 


\section{MAB}

\section{Administratieve proces}

Terwijl de aard van de strategie die een onderneming nastreeft, bepalend is voor het interne verrekenprijsbeleid, wordt, volgens Eccles, de uitvoering van dat beleid bepaald door het administratieve proces. Het gaat hierbij om: hoe de verrekenprijs wordt vastgesteld en door wie, op grond van welke gegevens, hoe vaak en naar aanleiding van welke veranderingen de verrekenprijs kan worden herzien en hoe conflicten worden geregeld.

\section{Typen verrekenprijsbeleid}

Eccles onderscheidt vier typen van verrekenprijsbeleid:

1 verplichte transacties tegen integrale kosten;

2 verplichte transacties gebaseerd op de marktprijs;

3 niet-verplichte transacties tegen een door de partijen vast te stellen verrekenprijs;

4 twee prijzen ('dual pricing'): marktprijs voor het leverende bedriffsonderdeel en integrale kosten voor het afnemende bedrijfsonderdeel.

Elk type kan worden gekarakteriseerd in termen van (a) de strategie waar het bij past, (b) de gevolgen voor de bevoegdheden en verantwoordelijkheden van de decentrale leidinggevenden, (c) de potentiële problemen bij het nemen van beslissingen en $(d)$ de potentiële problemen met betrekking tot de perceptie van 'fairness' door de leiding van de bedrijfsonderdelen

Het eerste type beleid: verplichte transacties tegen integrale kosten, is geschikt om een strategie van achterwaartse verticale integratie in te voeren. Met deze strategie wil de leiding bereiken, dat de kosten van het halffabrikaat worden verminderd. Door intern te produceren in plaats van extern in te kopen kan de onderneming besparen op de winstmarge, op vrachtkosten en op andere kosten die verbonden zijn aan een externe transactie. Om deze besparingen te kunnen realiseren zijn deze interne transacties van halffabrikaten dan ook verplicht, en worden deze afgewikkeld tegen integrale (standaard)kosten. Vanwege het verplichte karakter van de interne transacties zijn de bevoegdheden van de interne partijen beperkt. Het intern producerende bedrijfsonderdeel heeft ook beperkte verantwoordelijkheden, namelijk alleen voor de efficiëntie van de produktie. De verantwoordelijkheden van het op de markt verkopende bedrijfsonderdeel zijn groter, omdat dit bedrijfsonderdeel niet alleen verantwoordelijk wordt gehouden voor de efficiëntie van haar eigen produktie-activiteiten, maar ook verantwoordelijk is voor de resultaten van de verkopen van de eindprodukten op de markt. De invloed van de verrekenprijs op diverse beslissingen, zoals bezetting en investeringen, is gering, omdat bij deze beslissingen ook het hogere leidinggevende niveau betrokken is en aan investeringsbeslissingen speciale studies ten grondslag liggen, waarbij vooral gekeken wordt naar toekomstige ontwikkelingen.

Het tweede type beleid: verplichte transacties gebaseerd op de marktprijs, wordt volgens Eccles toegepast om alle overige strategieën van verticale integratie te implementeren. Bij deze strategieën van verticale integratie wordt de produktie van halffabrikaten gezien als een aparte business zowel ten aanzien van de interne als de externe transacties van het halffabrikaat. Om te voorkomen dat aan de externe transacties voorrang wordt gegeven, worden de interne transacties verplicht gesteld. De verantwoordelijkheden zijn bij dit type beleid voor het intern producerende bedrijfsonderdeel groter dan bij het eerste type beleid, omdat dit bedrijfsonderdeel nu wèl verantwoordelijk is voor de resultaten op de externe transacties van halffabrikaten. Door de nauwe relatie tussen het intern producerende bedrijfsonderdeel en het intern afnemende bedrijfsonderdeel kunnen er problemen ontstaan, als de bedrijfsonderdelen alleen op de eigen prestaties worden beoordeeld. Bij de beoordeling moet rekening gehouden worden met de interdependenties tussen beide bedrijfsonderdelen en de gevolgen ervan voor de financiële uitkomsten. 
Het derde type beleid: niet-verplichte interne transacties tegen een door de partijen vast te stellen verrekenprijs, wordt toegepast als er geen strategie is van verticale integratie. Ieder bedrijfsonderdeel wordt beschouwd als een aparte business met een eigen strategie. De bedrijfsonderdelen zijn vrij om de goederen en diensten of intern of extern te kopen respectievelijk te verkopen. Over het algemeen is de omvang van de interne transacties in deze situaties gering. Mocht één van de partijen beslissingen nemen die voor de desbetreffende partij optimaal zijn, maar vanuit het gezichtspunt van de gehele onderneming suboptimaal, dan zijn de consequenties echter relatief gering. Bij dit type beleid hebben de bedrijfsonderdelen veel bevoegdheden, en worden ze geheel verantwoordelijk gehouden voor de financiële resultaten die door het eigen bedrijfsonderdeel zijn behaald. De beoordeling en de beloning zijn dan ook gebaseerd op de financiële uitkomsten van de afzonderlijke bedrijfsonderdelen. De leiding van deze bedrijfsonderdelen heeft meer bevoegdheden voor wat betreft investeringsbeslissingen, bezettingsgraad en verkoopprijzen.

Het vierde type beleid: twee prijzen: marktprijs voor het leverende bedrijtsonderdeel en integrale kosten voor het afnemende bedrijfsonderdeel, kan zowel worden toegepast bij een strategie van verticale integratie als bij het ontbreken van een dergelijke strategie. In geval van een strategie van verticale integratie kan dit beleid worden toegepast, als er bij het beoordelen van de prestaties van het intern producerende bedrijfsonderdeel problemen zijn, die voortvloeien uit de wijze waarop de transacties worden afgerekend: interne transacties tegen integrale kosten en externe transacties tegen marktprijs. Voor de interne transacties wordt het intern producerende bedrijfsonderdeel dan alleen verantwoordelijk gehouden voor de kosten, terwijl het voor de externe transacties ook winstverantwoordelijkheid draagt. Het verrekenprijsbeleid van twee prijzen kan ook worden toegepast, als er een beleid wordt nagestreefd van niet-verplichte interne transacties. Om ervoor te zorgen dat het intern afnemende bedrijfsonderdeel de goederen intern koopt, zonder dat dit van bovenaf wordt opgelegd, wordt vastgesteld dat dit bedrijfsonderdeel de goederen kan kopen tegen integrale kosten. Doordat de interne producent de marktprijs krijgt betaald voor de interne transacties, is er voor dit bedriffsonderdeel geen enkele reden om externe transacties te prefereren boven interne transacties. Dit type verrekenprijsbeleid wordt volgens Eccles in de praktijk weinig toegepast vanwege de nadelen die eraan verbonden zijn. Deze nadelen hebben betrekking op de dubbeltelling van winsten (de winst van de totale onderneming is geringer dan de som van de winst van de afzonderlijke bedrijfsonderdelen) en de onduidelijkheid met betrekking tot de na te streven strategie.

\section{Organisatiemodellen}

Op grond van de criteria mate van verticale integratie en mate van diversificatie onderscheidt Eccles een viertal organisatiemodellen:

1 'collective organization', dat gekenmerkt wordt door een zeer geringe mate van verticale integratie en diversificatie;

2 'cooperative organization', waarin een hoge mate van verticale integratie wordt aangetroffen en een lage mate van diversificatie;

3 'competitive organization', dat zich onderscheidt door een hoge mate van diversificatie en een geringe mate van verticale integratie:

4 'collaborative organization', dat een hoge mate van verticale organisatie en van diversificatie heeft.

Bij Ieder model past een bepaald verrekenprijsbeleid.

In het model 'collective organization', dat volgens Eccles kenmerkend is voor kleine en jonge ondernemingen waarin weinig structuur aanwezig is, komen geen interne transacties voor. Hierdoor is er geen behoefte aan enigerlei vorm van intern verrekenprijsbeleid. Het model 'cooperative organization' wordt geken- 
merkt door nauwe, onderlinge relaties tussen de bedrijfsonderdelen. Daarom is een gemeenschappelijke strategie die gericht is op het belang van de totale onderneming, erg belangrijk. In dit type organisatie komen veel interne transacties voor, waarvoor een verrekenprijsbeleid van verplichte interne transacties tegen integrale kosten past. In de 'competitive organization' hebben de verschillende bedrijfsonderdelen hun eigen produktie- en verkoopfaciliteiten. De bedrijfsonderdelen opereren zeer zelfstandig: er is sprake van een hoge mate van delegatie van bevoegdheden en verantwoordelijkheden. In dit type organisatie bestaan er doorgaans, vanwege de hoge mate van diversificatie, weinig relaties tussen de verschillende bedriffsonderdelen, waardoor er tussen deze bedrijfsonderdelen relatief weinig interne transacties voorkomen. ${ }^{2}$ Het verrekenprijsbeleid wordt gekenmerkt door geen opgelegde interne transacties tegen prijzen die door de partijen zelf worden vastgesteld. Het model 'collaborative organization' heeft kenmerken van het coöperatieve model maar ook van het concurrerende model. Dit brengt met zich mee dat de decentrale leidinggevenden aan de ene kant moeten samenwerken, maar aan de andere kant ook met elkaar moeten concurreren bij de verdeling van de middelen van de onderneming. In dit type organisatie zijn de organisatiestructuur en de managementsystemen zeer complex. De verantwoordelijkheden van de decentrale leidinggevenden zijn groter dan hun bevoegdheden. In dit model zijn de interne transacties voorgeschreven vanwege de hoge mate van verticale integratie, en worden deze transacties verrekend tegen op marktprijzen gebaseerde verrekenprijzen. Want ieder bedrijfsonderdeel wordt door de hoge mate van diversificatie als een aparte business beschouwd.

Het model van Eccles op grond waarvan een onderneming zijn verrekenprijsbeleid kan bepalen c.q. beoordelen - aangeduid als 'the Manager's Analytical Plane' -, ziet er schematisch als volgt uit:
Figuur 1: Manager's analytical plane (ontleend aan Eccles, p. 274)

Vertical

$$
\text { High Cooperative Collaborative }
$$

integration

$$
\text { Low Collective Competitive }
$$

\section{Beïnvloedende factoren}

Uit ons onderzoek naar het functioneren van interne verrekenprijssystemen blijkt, dat er verschillende factoren van invloed zijn op de wijze waarop interne transacties worden bestuurd. ${ }^{3}$ Deze factoren zijn in te delen naar: 1 kenmerken van de organisatiecontext: 2 kenmerken van de interne transacties; 3 kenmerken van de betrokken partijen.

Systemen van interne verrekenprijzen bevatten regels voor de coördinatie van interne transacties. In gedecentraliseerde ondernemingen zijn er naast deze regels voor de coördinatie van interne transacties ook nog andere regels die gericht zijn op het tot stand brengen van de vereiste coördinatie van de activiteiten van de verschillende bedrijfsonderdelen. Gedacht kan worden aan de wijze waarop de bevoegdheden zijn verdeeld, de wijze waarop de bedrijfsonderdelen zich moeten verantwoorden over hun doen en laten en de uitkomsten daarvan, de wijze waarop deze uitkomsten worden vastgesteld enz. Al deze regels dienen op elkaar afgestemd te zijn om te bereiken dat de participanten in een onderneming het gewenste gedrag vertonen. Daarbij moet rekening worden gehouden met de gedragskenmerken van de participanten. Deze kenmerken beïnvloeden de wijze waarop de participanten tot beslissingen komen. Gaat het om coördinatie van interne transacties, dan wordt de aard van de coördinatie mede bepaald door de kenmerken van de interne transacties. Betreft het bijvoorbeeld interne transacties van goederen, waaraan de interne afnemer zeer specifieke eisen stelt die 


\section{MAB}

consequenties hebben voor het produktieproces van de interne leverancier, dan worden aan de coördinatiewijze andere eisen gesteld dan wanneer het gaat om standaardgoederen.

Bij kenmerken van de organisatiecontext gaat het om:

a organisatiestructuur, met als belangrijkste factoren de verdeling van de bevoegdheden en verantwoordelijkheden en de verdeling van de risico's verbonden aan interne transacties;

b wijze waarop de prestaties worden gemeten en beoordeeld, en de wijze van belonen;

c wijze waarop de gegevens worden verwerkt en verstrekt.

De volgende kenmerken van de interne transacties zijn van belang:

a mate van onzekerheid van de transactieomgeving;

b mate van gespecialiseerdheid van de investeringen ('asset specificity');

c omvang en frequentie van de interne transacties

De kenmerken van de betrokken partijen die een rol spelen, zijn:

a bounded rationality;

b kans op opportunistisch gedrag;

c mate van informatie-asymmetrie tussen de centrale leiding en de decentrale leidinggevenden enerzijds en tussen de leidinggevenden van de bedrijfsonderdelen anderzijds;

d risicohouding.

\section{Verschillen}

Wanneer we bovenstaande factoren vergelijken met het model dat door Eccles wordt gehanteerd, dan zijn de belangrijkste verschillen:

- aan de aard van de interne transacties wordt nauwelijks betekenis toegekend;

aan het informatie-aspect, met als aandachtspunten de wijze van gegevensver- werking en -verstrekking, het optreden van informatie-asymmetrie en de invloed hiervan op het gedrag van de partijen, wordt weinig aandacht besteed.

Het eerst genoemde verschilpunt kan worden teruggevoerd op het feit dat Eccles de strategie als gegeven beschouwd. Hij geeft geen verklaring voor waarom een onderneming een bepaalde strategie nastreeft. Het tweede verschilpunt heeft te maken met de betekenis die Eccles toekent aan de factor 'administrative process'. Deze factor heeft bij Eccles geen invloed op het verrekenprijsbeleid, maar speelt alleen een rol bij de implementatie van een bepaald beleid. In het model van Eccles is deze factor dan ook niet opgenomen. Als we evenwel kijken naar de elementen waaruit deze factor bestaat, dan moeten we constateren dat elementen als de verdeling van de bevoegdheid om de verrekenprijs te bepalen en eventueel te herzien, de informatieverwerking en -verschaffing en de wijze waarop eventuele conflicten moeten worden opgelost, wel degelijk elementen zijn die het beleid mede bepalen. Deze constatering heeft als consequentie, dat ook deze elementen een verklaring behoeven: waarom worden deze elementen ingevuld zoals ze zijn ingevuld?

De conclusie kan worden getrokken dat het model van Eccles te eenvoudig is. We hebben hiervoor reeds vastgesteld dat enerzijds de variabelen verticale integratie en diversificatie niet worden verklaard, en anderzijds variabelen die betrekking hebben op de aard van de transactie en de beschikbaarheid van informatie, niet worden meegenomen. Bekijken we het model nader, dan zijn feitelijk maar twee organisatiemodellen van belang, te weten het 'cooperative' model en het 'collaborative' model. Immers, in het 'collective' model komen geen interne transacties voor, en ook voor het 'competitive' model stelt Eccles vast dat tussen de gediversificeerde bedrijfsonderdelen maar weinig interne transacties zullen voorkomen (zie ook voetnoot 2).

Het is dan ook niet verwonderlijk dat het verklaren van het verrekenprijsbeleid van de door 


\section{MAB}

ons onderzochte ondernemingen aan de hand van het model van Eccles problemen geeft. ${ }^{4}$ Allereerst hebben we problemen met het vaststellen van welke strategie door de desbetreffende onderneming wordt gevolgd. Op welk niveau moeten we de strategie vaststellen? Nemen we bijvoorbeeld het concern Akzo, dan kunnen we daarbinnen verschillende divisies onderscheiden, waartussen weinig relaties bestaan. Maar kijken we naar de divisies, dan zien we dat iedere divisie een eigen strategie volgt als het gaat om verticale integratie en diversificatie. En wat moeten we aan met interne dienstverlening door concernonderdelen van DSM, zoals het verzorgen van het onderhoud bij de divisies, het verrichten van research in opdracht van de divisies? In de praktijk blijkt dat interne transacties op verschillende niveaus kunnen voorkomen: tussen concernonderdelen en divisies, tussen divisies, tussen businessgroepen (of werkmaatschappijen) van één divisie, tussen bedrijfsonderdelen behorende tot één businessgroep.

Uit het praktijkonderzoek komt verder naar voren, dat er voor de diverse interne transacties tussen de bedrijfsonderdelen, of het nu divisies, businessgroepen of verdere onderverdelingen zijn, verschillende regels kunnen zijn. Tevens constateren we dat de aard van de interne transacties, zelfs per bedrijfsonderdeel, kan verschillen. Kijken we op het niveau van de interne transacties, dan treffen we onder meer een situatie aan waarin sprake is van achterwaartse verticale integratie, maar waarbij de verrekenprijs wordt gebaseerd op de marktprijs. Volgens de theorie van Eccles zou een kostenbasis mogen worden verwacht. In een andere situatie hebben we te maken met voorwaartse verticale integratie met een verrekenprijs die gebaseerd is op kosten. Eccles verwacht een op de marktprijs gebaseerde grondslag. Voorts hebben we een situatie van verticale integratie aangetroffen, waarin de interne transacties weliswaar zijn voorgeschreven, maar waarbij de interne partijen via onderhandelingen de interne verrekenprijs en de overige contractvoorwaarden vaststelien. Eccles stelt dat onderhandelingen alleen voorkomen, als de interne partijen zelf mogen beslissen of zij intern dan wel extern transacties aangaan. Een dergelijk verrekenprijsbeleid komt alleen voor, aldus Eccles, als er geen strategie van verticale integratie is. Tevens zien we een situatie van verticale integratie, waarin zowel de interne transacties als de verrekenprijs niet zijn voorgeschreven.

Kortom, het model van Eccles biedt ons bij de analyse en het verklaren van het verrekenprijsbeleid in de praktijk weinig houvast. Voorts kunnen we vaststellen, dat we op het niveau van de (interne) transactie moeten gaan kijken om inzicht te krijgen in de besturingswijze.

\section{De betekenis van de aard van de transactie voor het verklaren van verticale integratie en de besturing van interne transacties}

Eccles onderscheidt twee vormen van verticale integratie: achterwaartse verticale integratie en overige vormen van verticale integratie. Daarbij vult hij achterwaartse verticale integratie op een zeer specifieke manier in. Het gaat erom dat het intern verkopende bedrijfsonderdeel niet als een apart bedrijf wordt beschouwd, maar als een onderdeel van het intern kopende bedrijfsonderdeel. Want in dat geval is het streven gericht op zo laag mogelijke kosten van de produkten van de interne leverancier en hoeft, door intern te produceren, geen winstmarge te worden betaald en kan worden bespaard op bepaalde kosten zoals transportkosten. Maar waarom kan dit ook geen argument zijn voor een achterwaarts geïntegreerde producent, die zijn produkten ook op de externe markt afzet? Bovendien zouden ook bij een niet-geintegreerde producent de transportkosten en wellicht nog andere produktiekosten kunnen worden verlaagd, indien de producent vlakbij de afnemer zou zijn gevestigd

Op dit type vragen geeft de transactiekostentheorie antwoord. Niet van belang is van welke vorm van verticale integratie sprake is, maar 
van belang is de aard van de transactie tussen producent en afnemer, hetgeen tevens van invloed is op de aard van de relatie tussen beide partijen. De gerichtheid op de interne transactie sluit aan bij de gedachten van Porter (1985), die stelt dat verticale integratie niet alleen moet worden beschouwd in termen van fysieke produkten en een heroverweging van het relatienetwerk met leveranciers en afnemers, maar ook in termen van activiteiten. Tevens stelt Porter dat de besturing van verticale verbindingen geen integratie vereist, maar dat integratie de mogelijkheid biedt dat de voordelen van verticale verbindingen gemakkelijker gerealiseerd worden. Volgens de transactiekostentheorie $^{5}$ is dit het geval als de transacties gekenmerkt worden door

hoge mate van onzekerheid:

hoge mate van gespecialiseerdheid van de investeringen (asset specificity)

hoge frequentie en omvang.

Transacties met deze kenmerken vereisen waarborgen voor de continuiteit van de relatie. omdat één of beide partijen ten behoeve van de transacties specifieke investeringen heeft/hebben gedaan, die in een andere aanwending een veel lagere waarde hebben. Deze investeringen kunnen betrekking hebben op fysieke produktiemiddelen, maar ook op menselijke kennis die al doende wordt verkregen, en op immateriële zaken in de verkoopsfeer zoals merkbeelden en merknamen (zie voor een beschrijving van de verschillende vormen van gespecialiseerdheid van de investeringen Williamson, 1985, p. 95 e.v. en Van der MeerKooistra, p. 113 e.v. en p. 268 e.v.). Omdat de onzekerheid van de transactie-omgeving groot is, is het niet mogelijk allesomvattende contracten af te sluiten. Als de omstandigheden veranderen, zullen er opnieuw afspraken moeten worden gemaakt. Daarbij kunnen de partijen zich opportunistisch gedragen en proberen gunstige aanpassingen te realiseren, die de andere partij kunnen benadelen. Vanwege de gespecialiseerdheid van de investeringen is het voor de benadeelde partij niet aantrekkelijk om de relatie te verbreken. Door derge- lijke transacties te integreren kunnen aanpassingen veel gemakkelijker en tegen lagere kosten worden gerealiseerd. omdat de kans op opportunistisch gedrag van partijen die tot één onderneming behoren, aanzienlijk geringer is. De beheerskosten of transactiekosten van transacties met deze kenmerken zijn dan ook veel lager, als ze binnen de onderneming worden afgewikkeld en niet via de markt lopen.

Williamson (1985, p. 105 e.v.) stelt dat alle vormen van verticale integratie op grond van overwegingen van transactiekosten kunnen worden verklaard, en dat een technische verklaring, die is gebaseerd op de benadering van de onderneming als produktiefunctie. over het algemeen ontoereikend is. Dit gaat ook op voor integratie van lokatiegebonden activiteiten van opeenvolgende produktiestadia. Technisch gezien hoeft er geen enkele belemmering te zijn om dergelijke activiteiten in afzonderlijke ondernemingen onder te brengen, maar als dergelijke transacties gepaard gaan met gespecialiseerde investeringen en onzekerheid kan bij integratie op de transactiekosten worden bespaard. Als er geen spra$k e$ is van gespecialiseerde investeringen en onzekerheid. dan biedt de markt voordelen. via de markt zijin voordelen van schaal en scope te realiseren, bovendien geeft de markt betere prikkels ter beheersing van produktiekosten en kosten van de bureaucratie

Ook als zich in gediversificeerde ondernemingen regelmatige transacties tussen divisies zouden voordoen, waaraan gespecialiseerde investeringen ten grondslag liggen, is het voor desbetreffende ondernemingen uit overwegingen van transactiekosten van belang dergelijke transacties voor te schrijven. De hoogte van de transactiekosten wordt niet bepaald door de aard van de strategie, maar door de kenmerken van de transactie.

\section{Conclusies}

Uit het vorenstaande kunnen we de volgende conclusies trekken met betrekking tot de be- 


\section{MAB}

sturing van interne transacties. Transacties die gekenmerkt worden door een hoge mate van gespecialiseerdheid van de investeringen en een hoge mate van onzekerheid, zullen binnen één onderneming worden aangegaan en afgewikkeld. Omdat de continuïteit van deze transacties van belang is, zullen dergelijke interne transacties van hogerhand worden voorgeschreven. Gaat het daarentegen om transacties waaraan geen gespecialiseerde investeringen ten grondslag liggen, dan is het verplicht opleggen van de interne transacties niet nodig. Dergelijke transacties kunnen net zo goed via de markt lopen, want als een marktpartij de relatie beëindigt, kan er zonder extra kosten een andere partij worden gevonden De kans is groot dat een marktrelatie voordeliger is, omdat er voordelen van schaal en/of scope kunnen worden gerealiseerd.

De aard van de transactie beïnvloedt het gedrag van de partijen. Door de transacties op een bepaalde wijze te coördineren kan het gedrag worden gestuurd. Zo kunnen de regels inzake interne transacties ertoe leiden, dat interne partijen er belang bij krijgen om rekening te houden met het doen en laten van concurrenten op de markt, of om tot uitwisseling van kennis te komen met concurrenten, leveranciers en afnemers. Welk beleid moet worden nagestreefd is mede afhankelijk van de aard van de gespecialiseerdheid van de investeringen. Uit onderzoek blijkt (Lundgren, 1990) dat als de gespecialiseerdheid is gelegen in menselijke kennis, het erg belangrijk kan zijn voor de verdere ontwikkeling van die kennis, dat de producent en afnemer nauw overleg hebben zowel in de ontwerp-, test- als uitvoeringsfase van een nieuw produkt. In een dergelijke situatie is het wenselijk, dat de regels inzake interne transacties aanzetten tot contacten met externe producenten en afnemers. Daarom is een nadere analyse van de aard van de gespecialiseerdheid van de investeringen noodzakelijk voor het ontwerpen van de wijze waarop interne transacties worden gecoördineerd.

\section{De betekenis van het informatie-aspect voor de besturing van interne transacties}

Als tweede verschil tussen de uitkomsten van ons onderzoek en het model van Eccles is het informatie-aspect genoemd. Eccles besteedt weinig aandacht aan de relatie tussen de wijze van gegevensverwerking en -verstrekking en de wijze van besluitvorming (centralisatie versus decentralisatie), terwijl hij als element van een intern verrekenprijssysteem wel de verdeling van de bevoegdheden inzake de keuze van de leverancier c.q. afnemer en de keuze van de verrekenprijs ziet. Uit ons onderzoek komt naar voren dat het informatieaspect een belangrijke rol vervult bij de wijze waarop interne transacties worden voorbereid, afgesloten en afgewikkeld, met andere woorden zowel in de ex ante als in de ex post fase van de transactie. Het gaat erom: wie beschikt of kan beschikken over welke informatie, welke informatie is nodig voor het nemen van een beslissing, is er verschil in informatie tussen de partijen van een transactie en welke consequenties zijn hieraan verbonden? Deze vragen zijn van belang voor het ontwerpen van de regels inzake interne transacties en voor de relatie tussen en het gedrag van de betrokken partijen. Met de betrokken partijen worden zowel de transactiepartners bedoeld als een hoger leidinggevend niveau, want bij de coördinatie van interne transacties zijn ten minste drie partijen betrokken.

De wijze van besluitvorming en daaraan verbonden de gegevensverwerking en -verstrekking berusten op een afweging van baten en kosten. Deze baten en kosten variëren al naar gelang het organisatieniveau waarop de besluitvorming en gegevensverwerking plaatsvinden. Als deze afweging van baten en kosten ten gunste uitvalt van de centrale leiding als beslisser, dan worden de beslissingsbevoegdheden niet gedelegeerd naar lagere leidinggevende niveaus. De informatie waarover een beslisser kan beschikken, is afhankelijk van de gegevensverwerking en -verstrekking in de onderneming, van de kennis en ervaring van de beslisser en van zijn inspanningsbereid- 
heid. Deze factoren zijn van invloed op de mate waarin de beslisser structuur aan een probleem kan geven, in hoeverre hij het beslissingsmodel begrijpt, en inzicht heeft in de veronderstellingen die ten grondslag liggen aan, en de regels die zijn gebruikt bij de verwerking van de gegevens. Hoe meer kennis in het geheugen van de beslisser is opgeslagen en hoe meer ervaring de beslisser met de oplossing van problemen heeft, hoe lager de kosten van de informatieverkrijging en hoe hoger de relevantie van de informatie die hij ontleent aan de gegevensverwerking. De kosten van de besluitvorming kunnen gelegen zijn in opportunistisch gedrag. Dit is gedrag dat zich uit in het nastreven van eigen doelstellingen, die strijdig zijn met de doelstellingen van de centrale leiding. Opportunistisch gedrag kan zich met name voordoen, wanneer er sprake is van informatie-asymmetrie. Informatie-asymmetrie tussen de partijen betrokken bij interne transacties zal zich vooral voordoen als:

- de transactie-omgeving zeer veranderlijk is;

- de onderneming omvangrijk en divers is;

- de problemen weinig gestructureerd zijn;

- de ervaring en kennis van de bestisser met betrekking tot een probleem gering is.

Interne transacties kunnen tot gevolg hebben, dat de beslissingen en acties van het ene bedrijfsonderdeel invloed hebben op de prestaties van het andere bedrijfsonderdeel, zowel met betrekking tot de inspanning als ook wat betreft de achteraf verkregen resultaten. Hoe groter deze externe effecten, hoe belangrijker het is dat er in de besluitvorming rekening mee wordt gehouden. Als er een grote mate van informatie-asymmetrie is tussen de centrale leiding en de leiding van de gerelateerde bedrijfsonderdelen, is het voor de centrale leiding moeilijk de invloed van de externe effecten te beoordelen. De kans dat de externe effecten in de besluitvorming zullen worden betrokken, is groter in het geval van besluitvorming in overleg tussen de bedrijfsonderdelen, dan in het geval van een eenzijdig dictaat van de centrale leiding dan wel van de leiding van één der bedrijfsonderdelen.

\section{Conclusies}

Welke consequenties heeft het informatieaspect, zoals hiervoor beschreven, voor de wijze waarop interne transacties worden gecoördineerd? De consequenties zijn van tweeërlei aard. In de eerste plaats heeft het invloed op de wijze van besluitvorming en wel op de delegatie van de besluitvorming rond interne transacties en het proces van de besluitvorming: wie beslist er over de interne verrekenprijs en de overige contractvoorwaarden, geschiedt de totstandkoming van het contract en ook de afwikkeling ervan in onderling overleg of is het vooral een administratieve aangelegenheid, hoe worden conflicten geregeld, welke gegevens moeten de partijen elkaar verstrekken? In de tweede plaats bepaalt het informatie-aspect de keuze van de grondslag voor de interne verrekenprijs en de overige contractvoorwaarden.

Ad 1: wijze van besluitvorming. We gaan ervan uit dat de interne transacties gespecialiseerde investeringen vergen. We hebben hiervoor gezien, dat in dat geval de continuilteit van de interne transacties belangrijk is, en dat daarom de interne transacties van hogerhand zullen worden voorgeschreven. De vraag is nu wie de transactievoorwaarden mag vaststellen. Als het hogere leidinggevende niveau goed op de hoogte is met de omstandigheden waaronder de interne transacties plaatsvinden, zal de hogere leiding deze voorwaarden bepalen. Het systeem van interne verrekenprijzen zal dan nauwkeurige regels bevatten, waarmee wordt vastgelegd tegen welke verrekenprijs en onder welke overige voorwaarden de interne transacties moeten worden aangegaan en afgewikkeld. Is het hogere leidinggevende niveau niet goed geïnformeerd, dan zal het aan de interne partijen waartussen transacties plaatsvinden, worden overgelaten om zelf afspraken te maken over de transactievoorwaarden. De wijze waarop deze voorwaarden worden bepaald, is vooral afhankelijk van de mate van onzekerheid waaraan de transactie onderhevig is. Is de onzekerheid groot, dan zullen de transactievoor- 
waarden achteraf regelmatig moeten worden aangepast aan de gewijzigde omstandigheden. Door deze aanpassingen via onderling overleg te regelen wordt voorkomen, dat één van de partijen zich opportunistisch gedraagt door de voordelen eenzijdig naar zich toe te halen. Het onderlinge overleg zorgt ervoor, dat de partijen elkaar informeren over de gevolgen van de aanpassingen voor eenieder. Bovendien is uit onderzoek gebleken, dat onderling overleg een coöperatieve houding bevordert (Ackelsberg en Yukl, 1979 en Chalos en Haka, 1990). Toch kan het zijn dat de partijen niet tot overeenstemming komen. Om langdurige onderhandelingen tegen te gaan en te voorkomen dat de onderlinge verhoudingen worden vertroebeld, wordt er van hogerhand een arbitrage-instantie aangewezen. Is de onzekerheid van de transactie-omgeving daarentegen gering, dan kunnen de partijen van tevoren aangeven, welke veranderingen zullen optreden en welke gevolgen deze zullen hebben voor de transactievoorwaarden. Er kunnen dan bij het aangaan van het contract regels worden afgesproken over de aanpassingen. Op deze manier is een administratieve afwikkeling van de transacties mogelijk en zijn onderhandelingen tussen de partijen niet nodig.

Ad 2: invulling van de contractvoorwaarden. Uit ons onderzoek blijkt dat bij de keuze van de grondslag voor de verrekenprijs en de overige transactievoorwaarden alsook bij tussentijdse wijzigingen hiervan het administratieve proces een belangrijke rol speelt. Er wordt namelijk gekozen voor een verrekenprijs en overige transactievoorwaarden die met behulp van eenvoudige en ondubbelzinnige procedures aan het bestaande administratieve systeem kunnen worden ontleend. Op deze wijze wordt bewerkstelligd, dat de kosten verbonden aan de werking van het systeem van interne verrekenprijzen zo laag mogelijk zijn. Omdat het administratieve systeem regelmatig en tijdig betrouwbare informatie moet verschaffen ten behoeve van beslissingen van verschillende aard en ook het systeem van interne verrekenprijzen regelmatige informatie behoeft, zullen deze informatiebehoeften op elkaar worden afgestemd. Zo constateren we bij de onderzochte praktijkgevallen dat waar het administratieve systeem geen inzicht kan geven in de kostprijzen van de produkten (vanwege het optreden van gemeenschappelijke kosten zou de toerekening ervan willekeurig zijn) en wel beschikt over betrouwbare informatie over de marktprijzen, de interne verrekenprijs wordt gebaseerd op de marktprijs. In een ander geval beschikt de administratie over nauwkeurige kosteninformatie, deels om tot vergelijkbare kostprijzen te kunnen komen tussen de werkmaatschappijen in de verschillende landen en deels om het beleid dat is gericht op verlaging van de produktiekosten, te kunnen ondersteunen. We zien dan dat de verrekenprijs is gebaseerd op kosten, en dat gedetailleerd wordt aangegeven hoe de verrekenprijs moet worden berekend.

\section{Algemene conclusie}

De gedachte van Eccles dat de coördinatiewijze van interne transacties aan moet sluiten bij het alomvattende coördinatiesysteem van een onderneming, wordt door ons onderzoek bevestigd. De verschillen met het model van Eccles zijn samen te vatten in de factoren: gespecialiseerdheid van de investeringen, onzekerheid en informatie-asymmetrie. De toestand van deze factoren beïnvloedt de wijze waarop interne transacties worden bestuurd: de rol van de centrale leiding, de relatie tussen de interne leverancier en de interne afnemer, de wijze waarop interne transacties worden aangegaan en afgewikkeld, en de wijze waarop conflicten worden opgelost. De belangrijkste relaties zijn in figuur 2 weergegeven.

Uit figuur 2 blijkt duidelijk dat het door ons ontwikkelde model ter verklaring van de coördinatiewijze van interne transacties complexer is dan het model van Eccles. Het biedt een alternatief voor de gedachten van Eccles. Ons model vereist informatie over de organisatiecontext, de externe transactie-omgeving, de 
Figuur 2: De wijze van coördineren van interne transacties en de beïnvloedende factoren

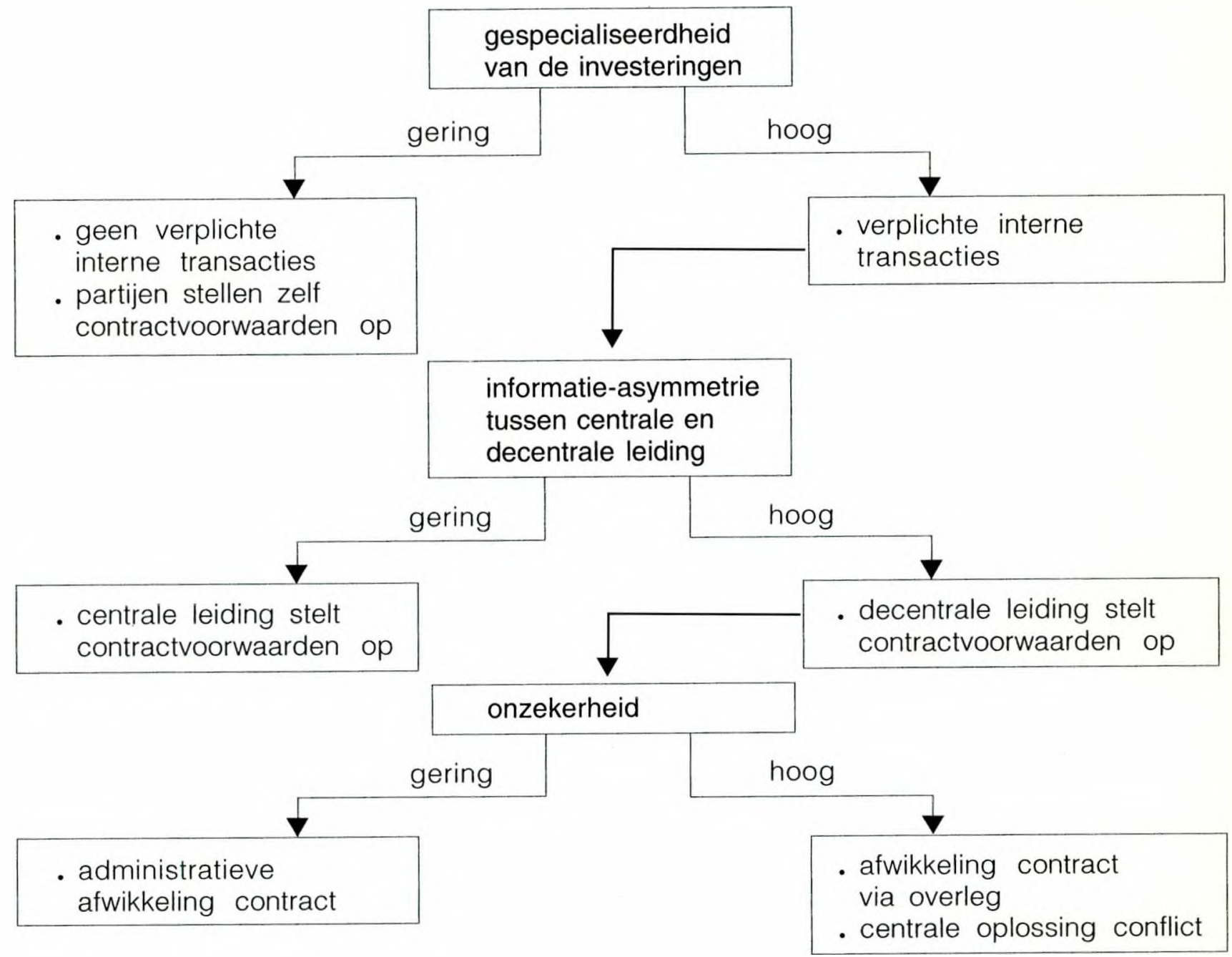

kenmerken van de transactie en de informatieverwerkende capaciteit van de betrokken partijen. Zonder deze informatie kan geen deugdelijk beleid worden geformuleerd. Dit beleid dient betrekking te hebben op alle fasen van een interne transactie, derhalve niet alleen op de fasen van het voorbereiden en afsluiten van het contract, maar ook op de fase waarin het contract wordt uitgevoerd en eventueel wordt herzien.

Een onderneming kan voordelen behalen door intern transacties aan te gaan, mits de transacties op een adequate wijze worden bestuurd. Interne transacties komen voor in ge- decentraliseerde ondernemingen. Dit is een ondernemingsvorm waarin zich ingewikkelde afstemmingsvraagstukken voordoen. De coördinatie van interne transacties is zo'n vraagstuk waarop vele factoren van invloed zijn.

\section{Literatuur}

Ackelsberg, R. en G. Yukl, Negotiated Transfer Pricing and Conflict Resolution in Organizations, Decision Scien ces, vol. 10, juli 1979 , p. 387-398

Bouma, J.L., Management Accounting in het kader van Economische Organisatietheorieën, Tijdschrift voor Bedrijfsadministratie, jrg. 96, september 1992, p. 196-205. 
Chalos, P. en S. Haka, Transfer Pricing under Bilateral Bargaining, The Accounting Review, vol. 65 , no. 3 , 1990, p. 624-641.

Eccles, RG., The Transter Pricing Problem: A Theory for Practice, D.C. Heath and Company, Lexington, Massachusetts, 1985.

Lundgren, K., Vertical Integration, Transaction Costs and 'Learning by Using', in: The Firm as a Nexus of Treaties, edited by Aoki, M., B Gustafsson en O.E. Williamson, Sage Publications Ltd, Londen, 1990, p. 112-132.

Meer-Kooistra, J. van der. Coördineren. Motiveren en Verrekenen: Wisselwerking tussen Omgeving. Onderneming en Mensen, Wolters-Noordhoff, Groningen, 1993.

Porter, M.E., Competitive Strategy: Techniques for Analyzing Industries and Competitors. The Free Press, New York, 1980

Porter, M.E., Competitive Advantage: Creating and Sustaining Superior Performance. The Free Press, New York. 1985

Vancil, R., Decentralization: Managerial Ambiguity by Design, Dow Jones-liwin. Homewood. Illınois, 1979.

Williamson, O.E., The Economic Institutions of Capitalism: Firms, Markets, Relational Contracting. The Free Press, New York, 1985.

\section{Noten}

1 De opzet en uitkomsten van het onderzoek zijn uitvoerig beschreven in Van der Meer-Kooistra, 1993. Het praktijkonderzoek is verricht bij DSM, Akzo, Unilever en Shell. De bevindingen van het praktijkonderzoek bij deze ondernemingen zijn, met uitzondering van het onderzoek bij Shell eveneens in genoemd werk opgenomen.

2 Het onderzoek van vancil (1979) bevestigt dat, als er sprake is van een hoge mate van diversificatie, de omvang van de interne transacties (als percentage van de totale omzet van desbetreffend bedrijfsonderdeel) beduidend geringer is dan wanneer de bedrijfsonderdelen van een onderneming nauw aan elkaar zijn gerelateerd. Ook uit ons praktijkonderzoek blijkt dit. Zo zijn er bijvoorbeeld weinig interne transacties tussen de verschillende divisies van Akzo, waarvan de produkten en markten onderling sterk verschillen. Daarentegen zijn er wel omvangrijke stromen interne transacties binnen iedere divisie, omdat daar wel sprake is van onderling gerelateerde activiteiten.

$3 \mathrm{Zie}$ voor een uitvoerige theoretische onderbouwing van het analysemodel, waarin deze factoren zijn opgenomen, hoofdstuk 4 van Van der Meer-Kooistra 1993, p. 92 e.v. 4 Voor een beschrijving van de uitkomsten van het praktijkonderzoek wordt verwezen naar de hoofdstukken 5, 6 en 7 van Van der Meer-Kooistra, 1993.

5 Voor een bespreking van de gedachten van de transactiekostentheorie kan worden verwezen naar Bouma 1992 